JURNAL ILMIAH MUQODDIMAH

Jurnal IImu Sosial, Politik, dan Humaniora

\title{
MENAKAR PERBEDAAN OPINI DALAM AGENDA PELAKSANAAN KONTESTASI PILKADA SERENTAK DI TENGAH COVID-19
}

\author{
Singgih Choirul Rizki ${ }^{1}$, Yusuf Adam Hilman ${ }^{2}$ \\ FISIP, Universitas Muhammadiyah Ponorogo \\ rizkymifta1113@gmail.com \\ adam_hilman@umpo.ac.id ${ }^{2}$
}

\begin{abstract}
Abstrak
Pelaksanaan Pilkada di tahun 2020 kali ini memang menuai segelintir problematika bagi pemerintah sekaligus masyarakat di dalamnya. Hal ini disebabkan oleh ancaman yang datang dari wabah Covid-19, sehingga menciptakan kewaspadaan ekstra terhadap pemerintah dan masyarakat di seluruh daerah dikarenakan wabah Covid-19 berpotensi untuk melemahkan imunitas dan kesehatan seseorang bahkan kematian. Tujuan utama yang menjadi topik dan prioritas utama untuk dikaji secara mendalam dalam penelitian ini adalah terkait dengan perkembangan opini publik yang bernada pro dan kontra dalam menyatakan sikap terhadap Pilkada di tahun 2020 ini. Metode yang dilakukan dalam penelitian ini adalah dengan studi kepustakaan, dan mencari berbagai macam referensi ilmiah seperti jurnal, pemberitaan, dan buletin sebagai data penguat penelitian. Hasil yang dapat disimpulkan dalam penelitian ini yakni tentang fakta munculnya perbedaan opini yang bernada pro dan kontra dari masyarakat, maupun pengamat politik. Kedua bentuk opini tersebut memiliki rasionalisasi yang sama karena didasarkan atas alasan-alasan logis di tengah situasi pandemi Covid-19 saat ini, dimana esensi nya adalah mengharapkan terciptanya kualitas demokrasi secara maksimal. Selain itu, persiapan dan pelaksanaan teknis juga menjadi tuntutan oleh kedua belah pihak kepada pemerintah, sehingga tidak ada pihak yang merasa dirugikan di kemudian hari.
\end{abstract}

Kata Kunci: Covid-19, Opini, Perbedaan, Pilkada

\begin{abstract}
The implementation of the election in 2020 this time indeed reap a handful of problems for the government as well as the society in it. This is caused by threats coming from the Covid-19 that make extra vigilance towards government and society in the all of region because Covid-19 outbreaks has the potential to weaken one's immunity and health, even death. The main objectives which are the main topics and priorities to be studied in depth in this research are related to the development of public opinion that has a pro and contra tone in expressing attitudes towards the local elections in 2020. The method used in this research is to study literature, and look for various kinds of scientific references such as journals, news, buletin as researches reinforcement data. The result that can be concluded in this research are about the fact of the emergence of differences of opinion that sound pro and contra from the public and political observes. Both forms of the opinion have the same rationalization because they are based on logical reasons in the current situation of the Covid-19 pandemic, where the essence is to expect the creation of maximum democracy quality. Beside of that, preparation and implementation is also a demand by both parties to the government, so that no party feels disadvantages in the future.
\end{abstract}

Keywords: Covid-19, Opinion, Difference, Local Election 


\section{PENDAHULUAN}

Pemerintah Indonesia beserta

DPR serta beberapa jajaran instrumen bangsa lainnya, baru-baru ini telah memberikan sikap dan kesepakatan untuk melanjutkan pelaksanaan Pilkada serentak yang sebelumnya sempat mengalami ketidakpastian dan penundaan akibat wujud antisipasi maupun kewaspadaan terhadap wabah Covid-19 di Indonesia. Perppu No.02 Tahun 2020 merupakan kesimpulan yang menjadi kesepakatan dari seluruh rapat kerja, yang pada esensi nya adalah tetap melaksanakan Pilkada dengan mengedepankan prioritas protokol kesehatan secara ketat (Merdeka, 2020).

Jika dicermati, sebenarnya pemerintah senantiasa berusaha untuk mengemban amanah konstitusi melalui dikeluarkannya Perppu No.02 Tahun 2020 tersebut. Namun permasalahannya adalah, saat ini Indonesia merupakan Negara dengan tingkat penyebaran Covid-19 yang belum terkendali. Di sisi lain, kesadaran masyarakat juga masih terlampau rendah dalam mengaplikasikan kaidah-kaidah kesehatan. Korelasi antara Pilkada dan kesadaran masyarakat memang begitu erat, dimana kedua aspek tersebut saling mengikat satu sama lain. Keterlibatan masyarakat adalah hal yang paling dominan dalam moment-moment politik seperti Pilkada, karena kekuatan massa dengan jumlah yang banyak memang sangat dibutuhkan oleh pihak-pihak yang berkepentingan.

Di Indonesia, fakta di lapangan menyebutkan bahwa perkembangan wabah Pandemi Covid-19 terus meningkat kasusnya secara signifikan, atau dalam arti lain adalah belum dapat dibendung secara total. Sehingga hal tersebut telah mendasari diputuskannya status darurat tentang kesehatan melalui Keppres No.11 Tahun 2011. Selain itu, bahaya dan ancaman yang ditimbulkan juga sejatinya meluas dan memenuhi hampir setiap bidang permasalahan bagi publik dan bagi pemerintah itu sendiri seperti ekonomi, sosial, moda transportasi (termasuk larangan mudik), bisnis, perdagangan, dan lain sebagainya. Mata rantai Covid19 menjadi permasalahan kolektif, sehingga berbagai implementasi kebijakan terus diupayakan hingga saat ini (Hasibuan, 2020).

Secara garis besar, pemerintah dan masyarakat dituntut untuk tidak menjadi abai terhadap segala perkara kecil selama masa pandemi Covid-19 berlangsung. Protokol kesehatan menjadi kunci utama saat ini, dalam menjamin pola dan interaksi sosial seluruh masyarakat. Pemerintah sebagai pihak berwenang, dalam hal ini memegang kendali terhadap perkembangan situasi maupun penyaluran kebijakan untuk menopang hajat hidup orang banyak. Sehingga kehidupan masyarakat tidak lepas dari kontrol penuh oleh pemerintah, namun di sisi lain juga tetap ada ruang kebebasan yang diberikan. Masyarakat dapat tetap menjalani aktivitas dan kesibukan sehari-hari, dengan syarat mematuhi segala himbauan teknis. Jika dikaitkan dengan pelaksanaan Pilkada mendatang, maka sebenarnya dapat dikatakan bahwa masyarakat juga memiliki peranan kunci untuk mendorong pihak pemerintah dalam rangka sinergi terhadap kesuksesan pelaksanaan Pilkada di tiap-tiap daerah melalui tingkat kesadaran 
yang tinggi. Dukungan dan kesadaran dari masyarakat memang sangat menentukan tentang sejauh mana suatu daerah akan mampu membendung laju penanganan Covid-19, atau justru malah membengkak dan semakin menambah daftar cacatan korban. Diakui atau tidak, Pilkada 2020 di Indonesia merupakan satu kontestasi politik yang perlu untuk dipertahankan kualitasnya, tanpa mengabaikan konsep protokol kesehatan.

Pilkada serentak merupakan upaya untuk menciptakan local accountability, political equity dan local responsiveness. Pilkada harus mampu membawa hasil yang menyeluruh, serta menghantarkan masyarakat untuk dapat merasakan perbaikan kondisi sosial, politik, dan ekonomi. Partisipasi masyarakat di tingkat lokal, adalah wujud dari adanya kemauan dan penerapan asas kedaulatan rakyat yang mengharapkan dampak nyata dalam menghasilkan output yakni untuk melahirkan pemerintahan baru (Arifulloh, 2015).

Upaya untuk melahirkan pemerintahan baru pada berbagai daerah di Indonesia, sejatinya mewujudkan suatu semangat kebangsaan dan harapan yang membumbung tinggi. Hal ini terus dibuktikan dengan konsistensi dari pelaksanaan Pilkada serentak dengan penuh tanggung jawab dan demokratis. Namun di tahun 2020 ini, baik pemerintah dan masyarakat Indonesia tentunya sama-sama memiliki kesadaran dalam membaca situasi yang sedang terjadi dimana wabah Covid-19 merupakan permasalahan utama dan perlu untuk disikapi secara bijak. Relasi antara masyarakat dan pemerintah, mungkin saja bisa disebut sebagai sinergi untuk melalui masa-masa sulit dalam kontestasi politik di tahun 2020 ini.

Agenda pelaksanaan Pilkada merupakan suatu agenda rutin yang mengandung langkah strategis bagi terciptanya transisi politik dan pemerintahan Indonesia di masa depan. Persoalan Pilkada bukan hanya terbatas pada karakteristik calon, mekanisme kampanye, maupun dinamika dan prosesi pelantikan semata. Keutamaan dari adanya Pilkada adalah dalam merangsang kesejahteraan dan pembangunan bagi masyarakat di tiap-tiap daerah melalui berbagai macam upaya pembangunan secara berkesinambungan. Koordinasi dari pemerintah pusat harus mencapai titik sasaran, dikarenakan tiap pemimpin daerah tentunya memiliki latarbelakang politik yang tidak sama (Arifulloh, 2015).

Pada masa darurat akibat pandemi Covid-19 seperti saat ini, segala manuver dan mekanisme politik menjadi lebih riskan. Para pelaku politik sudah pasti memiliki strateginya sendiri untuk terus mengerahkan massa, karena tujuannya adalah memenangkan kompetisi. Kemudian, hal itu biasanya juga turut diimbangi dengan antusiasme masyarakat dari berbagai penjuru yang larut dalam atmosfer politik rutin. Selalu ada semacam orientasi untuk berbenah, memihak, memilih, serta meyakini sosok pemimpin pilihan. Permasalahannya adalah, terkait dengan proses dan mobilisasi untuk melibatkan kehadiran massa tentu bukan tanpa resiko kecil. Hal ini menjadi berbeda jika berkaca dari pelaksanaan Pilkada sebelumsebelumnya yang berjalan normal, dimana seluruh pelaku politik selalu melakukan pola yang sama. 
Salah satu makalah internasional tentang Pemilu dan seputar Covid-19 yang telah diterbitkan oleh IDEA, sejauh ini telah menjadi dasar bagi Perludem Indonesia (Perkumpulan Untuk Demokrasi) dalam merumuskan tentang bagaimana wacana dan pandangan politik yang tepat untuk diterapkan di Indonesia dalam menyikapi Pilkada 2020. Makalah tersebut tidak lah mengikat, namun hanya sebatas memberikan pustaka referensi bagi tiap-tiap negara. Karena itu, pemerintah Indonesia terbilang cukup berani untuk mengeluarkan Perppu Nomor 2 Tahun 2020 sebagai suatu kebijakan luar biasa dalam sejarah demokrasi di Indonesia. Aspek legalitas yang dikeluarkan pemerintah Indonesia sebenarnya harus mampu untuk memberikan wawasan secara terurai, agar masyarakat juga paham tentang teknis yang akan dilakukan ke depannya. Selain itu, konsekuensi dari pelaksanaan Pilkada di tengah bencana (wabah Covi-19) juga berpotensi untuk menambah daftar panjang permasalahan (Habibi, 2020).

Pelaksanaan

Pilkada serentak yang telah secara resmi dimaklumatkan oleh Pemerintah Indonesia pada tanggal 9 Desember 2020 nanti, sejauh ini telah memberikan kejelasan serta gambaran kepada seluruh masyarakat. Pilkada serentak di tahun 2020 ini memang menuai berbagai macam opini, penafsiran, maupun kecenderungan untuk pro dan kontra. Fakta nya jadwal Pilkada di tahun ini sudah bukan lagi sebagai sekedar wacana belaka, ditambah lagi dengan situasi dan kondisi yang terjadi akibat Covid-19. Maka suatu hal lumrah apabila banyak opini dan tafsir dari berbagai tokoh maupun pemerhati politik yang banyak bermunculan untuk mengomentari status pelaksanaan Pilkada ke depan.

Tolok ukur nya adalah, tentang opini yang gencar dan dapat dibuktikan dari adanya bentuk gerakan petisi online untuk menunda pelaksanaan Pilkada 2020 di Indonesia hingga tahun 2021 atau secara tidak langsung adalah menunggu perkembangan situasi pandemi usai ataupun membaik. Mereka tergabung dalam kelompok sebagai Koalisi Sipil Masyarakat untuk Pilkada Sehat, dan menyatakan telah melakukan diskusi serta penyaluran aspirasi kepada pihak pemerintah. Gerakan petisi online ini sebenarnya didasari atas keinginan kuat pemerintah yang tidak telah disepakati, sehingga Pilkada 2020 tetap dijadwalkan untuk terlaksana beberapa bulan mendatang (Farisa, 2020b).

Menurut Nafis (2020) yang merupakan perwakilan dari kelompok penggerak petisi, menyatakan bahwa Pilkada yang akan berlangsung diprediksi akan menurun kualitasnya. Mulai dari keselamatan warga masyarakat, penyelenggara, aparat, dan instrumen lain juga menjadi terancam, walaupun Perppu darurat yang telah dikeluarkan juga mengatur tentang teknis protokol kesehatan sekali pun. Hal serupa juga dikatakan oleh salah satu inisiator petisi yakni Direktur Eksekutif Perludem, menurut Anggraini (2020) pelaksanaan Pilkada 2020 yang terkesan memaksakan tersebut akan lebih berpotensi menimbulkan banyak kerugian daripada manfaat yang dirasakan (Farisa, 2020b).

Selain itu, KPU menyatakan bahwa pihaknya siap untuk memulai 
simulasi pelaksanaan Pilkada dengan teknis-teknis khusus, termasuk tata cara baru dan penerapan protokol kesehatan di dalamnya. Dalam hal ini, KPU juga kembali mengaktifkan status para panitia penyelenggara (PPK, KPPS dan PPS) yang sebelumnya berstatus sebagai ad hoc akibat status darurat pandemi Covid-19. Antisipasi penularan Covid-19 menjadi pertimbangan serius bagi lembaga KPU, maka dari itu simulasi merupakan wujud dari kesiapan total, sebelum menghadapi pelaksanaan secara riil di lapangan nantinya (Farisa, 2020a).

Maka dari itu, penelitian ini menjadi menarik untuk dikaji sebagaimana penelitian sebelumnya oleh Hasibuan (2020) yang mengkaji tentang akibat dan dampak yang timbul akibat Covid-19 dan menyerang berbagai lini sektor termasuk dalam agenda penundaan Pilkada 2020, sehingga Pemerintah mengeluarkan kebijakan darurat (sebagai respon atas situasi pandemi yang juga darurat). Kondisi akibat Covid-19 memaksa para aktor dan penyelenggara Pilkada untuk terbatas interaksinya, sehingga hal tersebut menghambat kinerja maupun pergerakan para aktor politik. Namun jika merujuk kepada kondisi pandemi Covid-19 yang masih belum terkendali, maka sebaiknya Pilkada di 2020 ini memang ditunda total. Prioritas yang semestinya diutamakan adalah, tentang bagaimana negara memenuhi aspek dan kebutuhan fundamental bagi tiap warganya (kesehatan \& keselamatan). Secara teknis, KPU sudah membuat kebijakan yang tertuang dalam Keputusan KPU Nomor 179/PL.02$\mathrm{Kpt} / 01 / \mathrm{KPU} / \mathrm{III} / 2020$ mulai dari pelantikan panitia pemungutan suara, verifikasi pasangan calon, hingga fase pemutakhiran data pemilih. Akan tetapi, penundaan teknis saja tidak cukup untuk menjamin keselamatan orang banyak walaupun hal tersebut tergolong sebagai upaya untuk menekan penyebaran Covid-19 di Indonesia (Hasibuan, 2020).

Untuk mengetahui tentang sejauh mana perkembangan opini publik, serta dikaitkan dengan situasi dan kondisi di Indonesia saat ini dari berbagai segi. kesiapan, kesadaran, dan keinginan kuat dari seluruh elemen di Indonesia dapat diukur melalui penelitian ini. Bagaimanapun, permasalahan Covid-19 telah menjalar ke berbagai ruang dan lini di Indonesia. Kepastian untuk dapat mengakhiri wabah Covid-19 belum dapat diprediksi secara nyata, sehingga masyarakat tetap berada dan bertahan dengan pola hidup yang sama. Tak terkecuali dengan kontestasi Pilkada, dimana harapan publik untuk menyongsong perubahan menjadi terganggu, bahkan diwarnai dengan atmosfer kewaspadaan.

\begin{tabular}{llr}
\multicolumn{2}{c}{ Kekhawatiran } & tentang \\
turunnya & kualitas demokrasi \\
merupakan & satu hipotesis alami
\end{tabular}
yang muncul di benak masyarakat. Bagaimanapun, masyarakat adalah pihak yang paling berharap akan suatu perbaikan bagi kehidupannya masing-masing. Melalui Pilkada, masyarakat tiap daerah dapat menciptakan langkah awal perubahan, serta merasakan dampak ke depannya sesuai dengan harapan dan kebutuhan. Pilkada di masa pandemi Covid-19 ini, tentu memerlukan kerjasama dari berbagai pihak agar mengedepankan kepentingan bersama. 


\section{METODE PENELITIAN}

Metode yang dipakai dalam penelitian ini adalah dengan pendekatan studi kepustakaan (library research). Menurut Zed (2003) studi kepustakaan didefinisikan sebagai serangkaian aktivitas dan kegiatan yang mengacu kepada pengumpulan data-data pustaka, termasuk membaca, mencatat, maupun mengolah bahan penelitian. Ada kurang lebih 4 karakteristik bagi seorang peneliti yang memilih metode studi kepustakaan, diantaranya yakni: Pertama, penulis berhadapan langsung dengan data tekstual maupun angka. Kedua, peneliti tidak langsung terjun ke lapangan karena data perolehan dari penelitian dapat diperoleh dimana pun dengan sifat yang cukup. Ketiga, peneliti memperoleh data dan fakta dari peneliti lain yang relevan tanpa melalui observasi lapangan. Keempat, kondisi yang berkaitan dengan ruang dan waktu sehingga membatas peneliti untuk terjun langsung ke lapangan guna memperoleh data secara langsung (Supriyadi, 2017). Pengujian keabsahan data dalam penelitian ini menggunakan Triangulasi, sebagaimana yang dikatakan oleh Susan Stainback dalam (Bachri, 2010) bahwa triangulasi bertujuan untuk meningkatkan pemahaman para peneliti terhadap data dan fakta yang dimiliki. Triangulasi merupakan teknik pemeriksaan keabsahan data dengan analisis data dari berbagai sumber. Triangulasi memanfaatkan sesuatu di luar data, sebagai pengecek dan pembanding.

\section{HASIL DAN PEMBAHASAN \\ Memaknai Ulang Hakikat Pilkada Pilkada di Indonesia, merupakan ajang rutin 5 tahunan}

yang diselenggarakan dengan penuh prosesi untuk kemaslahatan hajat hidup orang banyak di berbagai daerah. Adapun prinsip dasar dari penyelenggaraannya adalah berdasarkan dengan konsensus bersama, dan dilaksanakan sesuai dengan kaidah demokratis. Masyarakat berperan sebagai subjek utama untuk menentukan jatuhnya pilihan pada masing-masing calon pemimpin dari berbagai latarbelakang. $\mathrm{Di}$ era modern ini, Pilkada muncul sebagai salah satu perhelatan politik yang bergengsi dan memenuhi ruangruang publik dari berbagai elemen.

Makna dari Pilkada sendiri, sebenarnya adalah tentang bagaimana muncul satu gerakan bersama dari rakyat melalui cara demokratis dengan kesamaan tujuan. Tujuan tersebut berorientasi pada lahirnya sosok pemimpin baru yang diyakini memiliki kompetensi untuk menjalankan tugas dan fungsinya dalam mengayomi masyarakat secara maksimal melalui pengelolaan dan kebijakan. Kesejahteraan masyarakat menjadi prioritas dan indikator utama sejak awal prosesi pilkada dihelat, sehingga melalui indikator itu maka akan tercipta suatu ekspektasi yang didambakan oleh masyarakat (Akbar, 2017).

Masyarakat yang ada di tingkat daerah, secara langsung akan terlibat dengan pelaksanaan Pilkada. Karena tujuan dari Pilkada adalah untuk membangun kemandirian dalam berpolitik, sehingga masyarakat dituntut untuk menentukan nasibnya sendiri selama periode 5 tahun ke depan sesuai dengan asas yang berlaku. Para calon pemimpin (kandidat), adalah perantara bagi masyarakat untuk memulai harapan baru dan 
meneruskan langkah pembangunan yang sesuai dengan kehendak masyarakat itu sendiri.

$$
\text { Secara garis besar, }
$$

pelaksanaan Pilkada adalah

berdasarkan dengan kedaulatan masyarakat Indonesia di tiap daerah. Masyarakat memiliki kebebasan yang utuh dalam menentukan suara hak pilih nya tanpa ada intervensi dari pihak mana pun, termasuk para pelaku dan elite politik yang memang berkepentingan praktis. Kepentingan bersama merupakan agenda bersama yang harus disadari dan diupayakan oleh rakyat, termasuk dalam melakukan monitoring terhadap segala kebijakan publik. Kepastian untuk terciptanya ruang kebebasan bagi rakyat pada ajang Pilkada harus lah diperhatikan secara serius, serta dijamin keberadaannya sehingga mampu untuk mencerminkan kualitas partisipasi yang baik (Saputra \& Asih, 2017).

Estafet kepemimpinan yang ada dalam Pilkada, merupakan bagian dari prinsip otonom dengan turut melibatkan kehadiran rakyat sebagai faktor pendukung utama. Terciptanya ajang Pilkada adalah sangat membutuhkan modal sumber daya manusia sebagai motor penggerak yang mumpuni dan mampu untuk mengisi kekosongan tampuk kepemimpinan daerah. Prinsip yang terkandung dalam Pilkada, pada dasarnya lebih menekankan pada keadilan sosial tanpa meruncingkan perbedaan sekecil apapun (termasuk bagi individu maupun kelompok).

Maraknya partai politik juga semakin menambah dinamika Pilkada di Indonesia, karena runtutan persaingan yang berlangsung dalam jangka waktu yang lama. Kekalahan dan kemenangan secara angka, bukan lah hal yang mutlak untuk sekedar dijadikan pesta fora belaka. Namun, Pilkada juga sekaligus turut menyiratkan pesan bahwa tahuntahun berikutnya berpotensi untuk diwarnai dengan berbagai macam persaingan, dengan strategi masingmasing para pelaku politik.

\section{Perkembangan Opini Penolakan Terhadap Pilkada 2020}

Dikutip dari SerambiNews (2020), pernyataan sikap menolak juga disampaikan oleh salah satu pimpinan lembaga DPD RI Teras Narang. Dalam sesi wawancara dengan para wartawan, dirinya mengatakan:

"Sementara di saat bersamaan, kita sama-sama mengetahui bahwa seluruh dunia dan Indonesia sedang berjuang menghadapi wabah pandemi Covid-19, termasuk para pemerintah daerah yang hingga hari ini masih terus bekerja dan mengendalikan penyebaran Covid19 di daerahnya masing-masing".

Selain itu, ada beberapa pertimbangan resmi dari WHO sebagai badan kesehatan dunia yang menetapkan pandemi Covid-19 sebagai wabah global, serta statusnya masih aktif hingga sekarang. Pilkada 2020 setidaknya melibatkan sekitar 105 juta penduduk, di 270 daerah dari berbagai penjuru yang tentunya rawan dan rentan (Eda, 2020).

Penolakan tegas yang disampaikan oleh seorang Teras Nawang merupakan suatu pandangan rasional, dengan menjadikan acuan dan fakta lapangan sebagai pertimbangan kasus. Fakta nya saat ini Indonesia masih terus mengalami pertambahan kasus yang tak terkendali, sehingga tingkat kekhawatiran yang hinggap pada 
masyarakat pun turut meningkat. Maka dapat dipastikan bahwa di luar sana, tidak jarang juga banyak publik yang memiliki kecenderungan dan orientasi pemikiran seperti seorang Teras Nawang.

$$
\text { Bagaimana }
$$

pun,

kemaslahatan orang banyak adalah prioritas utama yang memang harus dikuatkan oleh Pemerintah dalam suatu negara, supaya apabila timbul kerugian nantinya tidak menjadi persoalan tambahan yang malah menambah beban bagi daerahdaerah. Adanya perkembangan opini publik, di sisi lain merupakan satu parameter bagi pemerintah pusat untuk kembali memantapkan langkah ke depan untuk menyambut Pilkada 2020 pada 9 Desember mendatang. Persiapan dan kewaspadaan yang extra tentu menjadi begitu vital untuk segera diimplementasikan dalam jangka pendek ini. Ketika perkembangan opini publik tidak dapat dibendung, maka satu-satunya cara yang bisa dilakukan oleh pemerintah adalah memunculkan satu ide dan gagasan alternatif baru sebagai upaya solutif.

Pro kontra dalam menanggapi rencana pelaksanaan Pilkada 2020 di tengah Covid-19 memang sangat menarik untuk diperbincangkan. Jelas saja banyak elemen masyarakat dari berbagai latarbelakang yang memiliki kesamaan pandangan, lalu berkelompok untuk menyampaikan pandangan tersebut. Hal yang pasti adalah, ide dan gagasan yang dimiliki oleh kelompok mana pun adalah suatu kelumrahan di Indonesia sebagai negara dengan landasan demokrasi yang notabene selalu menampung segala delik permasalahan publik. Tak ayal jika Pilkada 2020 pada 9 Desember mendatang juga mendapat kecaman, yang didasari atas rasa kewaspadaan dan kecemasan akibat belum terkontrol nya kasus penularan Covid-19 di Indonesia.

Dikutip dari prfmnews.id (2020), opini dan pandangan sejenis juga muncul dari lembaga Perludem (Perkumpulan untuk Pemilu dan Demokrasi) yang diwakili oleh Fadli Ramdhani, sebagaimana memberikan pernyataan pada saat On Air di salah satu stasiun Radio lokal (Firmansyah, 2020): Fadli: "Rancangan KPU kalau Pilkada digelar pada Desember, maka tahapannya harus dimulai sejak 15 Juni 2020. Masuk akal ga kalau kita paksakan Pilkada di Desember sementara kondisi pandemi masih terus menyerang?"

Fadli: "Dalam Perppu No.02 Tahun 2020, regulasi serta mekanisme selama pandemi tidak diatur dengan jelas. Mulai dari teknis kampanye, pemungutan suara, sampai pada tahap rekapitulasi"

Fadli: "Jumlah TPS bertambah, karena kesepakatan bersama untuk membatas per TPS hanya 500 orang. Otomatis alokasi jumlah anggaran juga bertambah, seperti APD dan alat pelindung lainnya"

Mencermati tentang apa yang disampaikan oleh Fadli sebagai perwakilan dari Perludem, setidaknya memang terdapat kewaspadaan dan kekhawatiran dengan menjadikan keselamatan masyarakat sebagai tujuan utama. Pelaksanaan Pilkada pada 9 Desember memang terkesan terburu-buru, di tengah fakta pandemi yang masih belum melandai grafik nya.

Opini kontra terhadap pelaksanaan Pilkada tersebut akan lebih meyakinkan, jika dikaitkan dengan info grafis maupun data 
sebaran yang memuat jumlah korban meninggal beserta jumlah korban yang statusnya terinfeksi Covid-19.

\section{Bentuk Opini Dukungan Terhadap Pilkada 2020}

Gambar 1. Konferensi Pers Aliansi Rakyat Demokrasi Jawa Timur

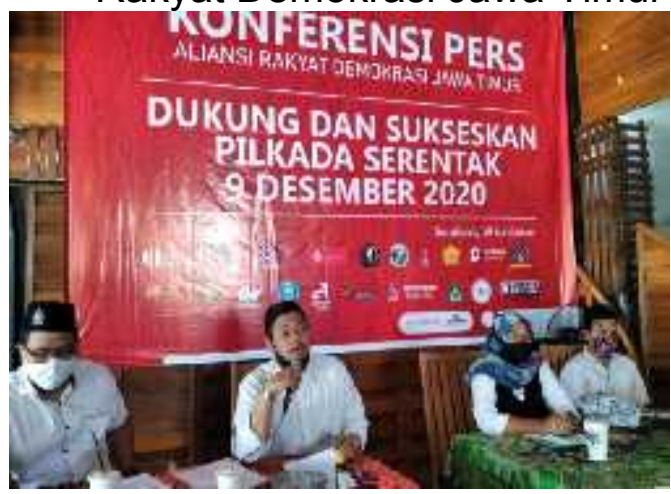

Sumber : Kumparan, 2020

Dikutip dari (Kumparan, 2020) opini lain justru datang dalam bentuk dukungan terhadap kesuksesan atas pelaksanaan Pilkada 2020 yang mana datang dari 21 organisasi. Gabungan organisasi tersebut menamai dirinya dengan Aliansi Rakyat Demokrasi Jawa Timur. Pesan yang hendak disampaikan kepada seluruh masyarakat adalah, untuk tetap berfikir positif dan selalu menerapkan protokol kesehatan dalam menyambut Pilkada pada 9 Desember nanti. Selain itu, Aliansi gabungan tersebut juga menganggap bahwa Pilkada di 2020 ini merupakan suatu tantangan bersama yang memang harus dihadapi dengan sikap bijaksana atau dalam arti lain adalah saling bahu membahu untuk turut mensukseskan.
Adapun beberapa poin utama sesuai dengan hasil konferensi pers yang digelar adalah sebagai berikut:

a) Mendukung Pelaksanaan Pilkada 2020 tanpa proses illegal seperti kampanye hitam, politik uang, politik identitas, berita hoax maupun segala cara yang tidak lazim.

b) Mendukung Pilkada pada 9 Desember dan mengharapkan terciptanya asas JURDIL (Jujur dan Adil) dan LUBER (Langsung Umum Bebas Rahasia).

c) Mendukung Penyelenggara Pemilu terutama KPU untuk secara gencar dan maksimal agar menerapkan protokol kesehatan, serta mempersiapkan peralatan pendukung yang memadai untuk dipergunakan di lapangan nantinya seperti APD, hand sanitizer, penyemprotan disinfektan, dsb.

d) Mendukung Pemerintah Daerah agar meningkatkan kewaspadaan terhadap gejala dan penularan Covid-19 di daerah masing-masing.

e) Menuntut KPU untuk membuat peraturan yang melarang bentuk kampanye dengan melibatkan banyak orang terutama bagi wilayah dengan status zona merah, dan menggantinya secara virtual (online). Namun untuk wilayah dengan zona hijau, mendukung untuk melakukan kampanye normal secara terbatas dan tetap menerapkan protokol kesehatan secara berkala.

f) Mendukung Pemerintah dan pihak penyelenggara Pilkada 
untuk gencar melakukan sosialisasi secara berkala dan rutin kepada masyarakat luas tentang pengetahuan seputar Pilkada di masa Pandemi Covid-19 baik dalam tahap persiapan, hingga tahap pemungutan di bilik suara.

g) Mengajak seluruh elemen masyarakat Indonesia terutama masyarakat Jawa timur yang datang dari berbagai latarbelakang, untuk sama-sama menyatukan semangat dan membantun mindset positif dalam menyambut keputusan pelaksanaan Pilkada dengan tetap patuh terhadap protokol kesehatan.

Gambar 2. Proses Penandatanganan Deklarasi

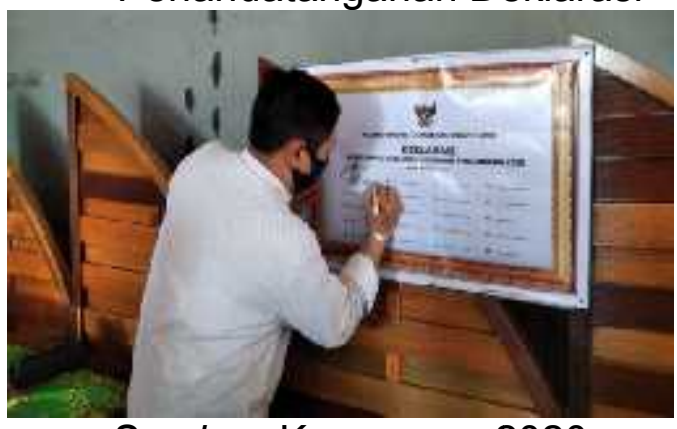

Sumber: Kumparan, 2020

Pada dasarnya, 21 organisasi dari berbagai latar belakang yang tergabung dalam Aliansi Rakyat Demokrasi di atas adalah mewujudkan suatu komitmen dan kepedulian yang kuat terhadap nasib Pilkada di masa Pandemi pada 9 Desember nanti.

Aliansi Rakyat Demokrasi tersebut tetap memberikan perhatian dan prioritas utama kepada keselamatan masyarakat secara keseluruhan, serta secara tidak langsung juga mengajak masyarakat untuk menjaga pola hidup sehat di wilayahnya masing-masing. Tidak hanya itu, mereka juga secara tidak langsung memberikan tuntutan kepada para pelaku politik untuk bijak dalam berkompetisi sesuai dengan prosedur dan kode etik. Agar tidak melakukan segala cara hanya untuk meraih kemenangan semata.

\section{Analisis Terhadap Fakta di Lapangan}

Gambar 3. Data Sebaran Covid-19 Per 16 Juni 2020

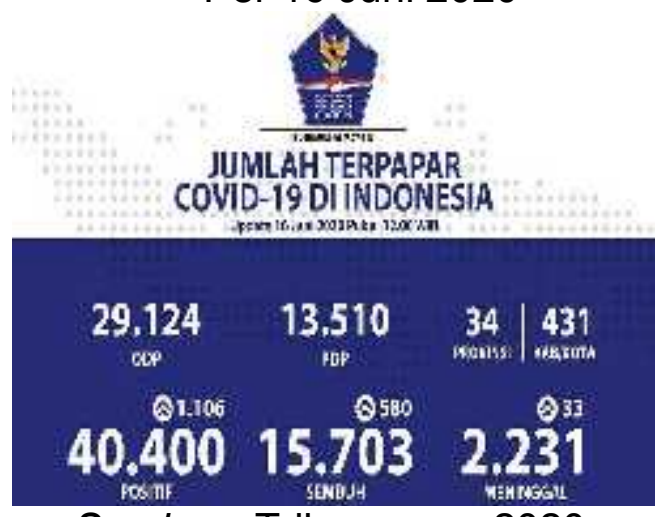

Sumber: Tribunnews, 2020

Dikutip dari (Kurniandari, 2020) bahwa jumlah penambahan kasus positif Covid-19 di Indonesia masih terus melonjak, dengan menempatkan Jawa Timur sebagai yang terbanyak (dari total 34 Provinsi). Walaupun terdapat jumlah kesembuhan yang terjadi, namun angka nya masih sangat timpang jika dibandingkan dengan angka kasus penambahan (positif). Secara tidak langsung, data tersebut juga berpotensi memunculkan pertanyaan besar bagi publik dan para pemerhati kebijakan pemerintah. Yakni tentang sejauh mana Indonesia mampu dan siap dalam prosesi pelaksanaan Pilkada 2020 pada 9 Desember mendatang? mengingat masih maraknya penyebaran terjadi di berbagai daerah.

Andaikan pemerintah beserta 
lembaga penyelenggara telah mengaku siap dan berkomitmen secara serius untuk memaksimalkan tahapan persiapan dan menggencarkan sosialisasi hingga tahap pemungutan suara, maka satu hal yang tidak boleh untuk dilupakan adalah terkait dengan bagaimana kesadaran maupun tingkat kedisiplinan masyarakat. Ketika tingkat kedisiplinan masyarakat rendah, apalagi sosialisasi yang dilakukan juga minim maka hal ini benar-benar akan memicu persoalan baru.

Selanjutnya juga muncul pertanyaan tentang sejauh mana kesiapan publik untuk memahami teknis Pilkada 2020 mendatang, dimana mekanisme nya telah berubah. Singkatnya, parameter ini juga mampu menjadi gambaran jelas bagi pihak berwenang (pemerintah \& lembaga pemilu) untuk lebih menitikberatkan kompleks nya permasalahan kepada orientasi kepentingan bersama sehingga langkah yang diambil nantinya tidak akan mengecewakan banyak pihak, bahkan tergolong merugikan.

Dinamika persoalan yang muncul akibat Covid-19 saat ini menjadi persoalan universal dan mendasar, di sisi lain pemerintah beserta lembaga terkait bersikukuh untuk tetap memulai kontestasi Pilkada 2020 pada 9 Desember mendatang.

Selama ini, Indonesia memang belum pernah mengalami masa-masa pelaksanaan Pilkada dalam ancaman wabah yang secara sifat berpotensi tinggi dalam mempengaruhi kesehatan manusia bahkan kematian. Fakta tentang Covid-19 hingga hari ini terus mengalami perkembangan kasus. Sehingga bisa dikatakan bahwa pemerintah dan masyarakat juga dilematis serta di sisi lain juga berjuang total untuk tidak kehilangan hak-hak politiknya di tahun 2020 ini.

Hal di atas sebenarnya sejalan dengan pendapat dari Beetham (2002) yang mengatakan bahwa konsep dasar dari demokrasi adalah political equality, dengan prinsip keadilan dan kesetaraan harus melekat pada masing-masing rakyat secara individu, sehingga rakyat mampu untuk menjalankan peran dan fungsinya dalam demokrasi (Apriani et al., 2020). Permasalahannya adalah, wabah akibat Covid-19 yang memaksa pemerintah dan masyarakat untuk berfikir ulang serta mempersiapkan skema baru dalam melaksanakan pesta demokrasi ke depan, sesuai dengan dinamika lapangan tentunya. Berbagai macam analisis bisa saja diterapkan, untuk mengukur tentang sejauh mana persiapan dan kesiapan masing-masing elemen dalam Pilkada nantinya. Analisis SWOT juga memiliki relevansi yang kuat, jika diaplikasikan dengan kasus yang tejadi di Indonesia saat ini. Kesederhanaan konsep dari analisis SWOT, akan mampu memberikan gambaran sekaligus pemetaan bagi pemerintah pusat dan daerah dengan kalkulasi masing-masing. Baik dari segi kekuatan, kelemahan, peluang, dan ancaman, merupakan serangkaian permasalahan yang muncul dari internal serta eksternal yang hanya mampu untuk dianalisis.

Ketika pemerintah mampu untuk melakukan analisis secara tajam, maka secara otomatis tingkat resiko yang dikhawatirkan dari pelaksanaan Pilkada di tengah ancaman wabah Covid-19 juga akan menurun. Kemudian, adanya keputusan hukum berupa Perppu No.02 Tahun 2020 tentang 
pelaksanaan Pilkada di 9 Desember sejatinya memang harus mampu untuk memecahkan problematika di lapangan. Di tengah wabah Covid19 ini, pilihan untuk mengupayakan keselamatan rakyat banyak sebagai prioritas adalah bagian dari tugas fundamental pemerintah dalam penyelenggaraan negara dengan sebaik-baiknya.

\section{KESIMPULAN DAN SARAN}

Pemahaman tentang bahaya Covid-19 di tengah arus Pilkada adalah kewajiban bagi pemerintah dan rakyat untuk sama-sama menyadari secara total. Namun tidak hanya sebatas itu, bahwa Pilkada juga menjadi bagian penting untuk mampu menuai hasil maksimal tanpa merugikan orang banyak walaupun terdapat berbagai macam hambatan yang menyertai. Kualitas dari pelaksanaan Pilkada tentunya menjadi penting untuk dijunjung tinggi, dengan memenuhi prinsip ideal dan legal. Pemerintah dan masyarakat tentu memiliki cara pandang yang tidak mungkin selamanya bisa sama, dikarenakan banyaknya faktor pengaruh. Selain itu, dinamika keadaan yang muncul akibat Covid-19 juga turut mewarnai kompleksitas permasalahan saat ini.

Pro kontra yang timbul akibat Covid-19, pada akhirnya menjadi polemik baru dan memunculkan output hukum berupa Perppu No.02 Tahun 2020 yang mana dimaksudkan untuk menjembatani antara hak dan kewajiban secara seimbang. Opini yang bernada pro, tentu menginginkan terciptanya kualitas demokrasi yang baik melalui mekanisme dan prosedur tertentu walaupun di tengah ancaman wabah. Kemudian, opini yang bernada kontra adalah bagian dari kekhawatiran dan kepedulian terhadap pemerintah dan masyarakat di tingkat daerah. Pada esensi nya, kontra terhadap pelaksanaan Pilkada 2020 adalah sesuatu yang juga rasional. Sehingga jika ditarik kesimpulan, keduanya tidak memiliki perbedaan tentang arah dan tujuan yang diinginkan untuk kepentingan orang banyak. Pemerintah, masyarakat, penyelenggara, aktor dan pelaku politik adalah keseluruhan pihak yang sama-sama terhambat. Akan tetapi dari kesemuanya, tentu pihak pemerintah adalah otoritas paling besar yang mampu untuk menampung segala aspirasi serta menciptakan jalan keluar baru untuk menghadapi tantangan Pilkada di tahun ini.

Pemerintah Indonesia sebaiknya mulai menjalin komunikasi dan konsolidasi dengan pemerintah daerah, beserta instrumen penyelenggara Pilkada secara lebih intens. Selain itu, perlunya sosialisasi bagi warga masyarakat di seluruh daerah juga menjadi vital untuk diagendakan secara khusus, mengingat Pilkada di tahun 2020 ini juga berada dalam situasi darurat akibat bencana wabah Covid-19. Artinya opini publik yang saat ini berseteru, harus dijadikan dasar untuk menentukan langkah susulan ke depan. Selain itu, keputusan maupun kebijakan susulan yang dibuat harus lah menjembatani kepentingan orang banyak tanpa menitikberatkan pada kecenderungan terhadap salah satu kelompok masyarakat.

\section{DAFTAR PUSTAKA}

\section{Jurnal IImiah}

Akbar, I. (2017). Pilkada Serentak Dan Geliat Dinamika Politik Dan Pemerintahan Lokal Indonesia. CosmoGov, 2(1), 95. https://doi.org/10.24198/cosmogov. 
v2i1.11852

Apriani, K. D., Made, N., \& Amanda, R. (2020). Tahapan Pemilu 2019 di Tengah Ancaman Bencana Alam: Studi Kasus Erupsi Gunung Agung. JURNAL BALI MEMBANGUN $B A L I, 1$ (April).

Arifulloh, A. (2015). Pelaksanaan Pilkada Serentak Yang Demokratis, Damai Dan Bermartabat. Jurnal Pembaharuan Hukum, II(2), 301-311.

Bachri, B. S. (2010). Meyakinkan Validitas Data Melalui Triangulasi Pada Penelitian Kualitatif. Teknologi Pendidikan, 10, 46-62.

Saputra, I., \& Asih, N. W. (2017). Kepemimpinan perempuan dan pilkada serentak. Aristo, 5(1), 141162.

https://doi.org/10.24269/ARS.V5I1. 424

Supriyadi, S. (2017). Community of Practitioners: Solusi Alternatif Berbagi Pengetahuan antar Pustakawan. Lentera Pustaka: Jurnal Kajian IImu Perpustakaan, Informasi Dan Kearsipan, 2(2), 83. https://doi.org/10.14710/lenpust.v2i 2.13476

\section{Buletin IImiah}

Habibi, A. (2020). Upaya Menyelamatkan Pemilihan Umum Di Tahun 2020. Adalah: Buletin Hukum Dan Keadilan, 4, 167-172.

Hasibuan, R. P. P. M. (2020). Urgensitas Perppu Pilkada Di Kala Wabah Pandemi Covid-19. ADALAH: Buletin Hukum Dan Keadilan, 4, 121-128.

\section{Media Online}

Eda, F. W. (2020). Komite I DPD Kembali Tolak Pilkada Serentak 9 Desember 2020, Ini Alasannya Artikel ini telah tayang di serambinews.com dengan judul Komite I DPD Kembali Tolak Pilkada Serentak 9 Desember 2020, Ini Alasannya, https://aceh.tribunnews.com/2020/ 06/10/komite-i.

https://aceh.tribunnews.com/2020/ 06/10/komite-i-dpd-kembali-tolakpilkada-serentak-9-desember2020-ini-alasannya

Farisa, F. C. (2020a). KPU Akan Gelar Simulasi Pilkada di Tengah Pandemi Covid-19.

https://nasional.kompas.com/read/2020 /06/12/22572791/kpu-akan-gelarsimulasi-pilkada-di-tengah-pandemicovid -19 ?page $=$ all

Farisa, F. C. (2020b). Masyarakat Galang Petisi Penundaan Pilkada di Tengah Pandemi Covid-19. https://nasional.kompas.com/read/2020 /05/28/05000041/masyarakat-galangpetisi-penundaan-pilkada-di-tengahpandemi-covid-19?page=all

Firmansyah, R. (2020). Perludem Sebut Pilkada Serentak di Tengah Pandemi Terlalu Dipaksakan. https://prfmnews.pikiranrakyat.com/nasional/pr13396213/perludem-sebut-pilkadaserentak-di-tengah-pandemi-terlaludipaksakan?page $=2$

Kumparan. (2020). PERNYATAAN SIKAP ALIANSI RAKYAT DEMOKRASI JAWA TIMUR 2020. https://kumparan.com/banyuwangi_con nect/pernyataan-sikap-aliansi-rakyatdemokrasi-jawa-timur-20201tddqd8Gw5A

Kurniandari, R. (2020). UPDATE Sebaran Virus Corona di Indonesia Selasa (16/6/2020): Lagi, Jatim Catat Kasus Baru Terbanyak Artikel ini telah tayang di Tribunternate.com dengan judul UPDATE Sebaran Virus Corona di Indonesia Selasa (16/6/2020): Lagi, Jatim Catat Kasus Baru Terban. https://ternate.tribunnews.com/202 0/06/16/update-sebaran-viruscorona-di-indonesia-selasa1662020-lagi-jatim-catat-kasusbaru-terbanyak

Merdeka. (2020). Pilkada Serentak Disepakati Digelar 9 Desember 2020.

https://www.merdeka.com/politik/pil kada-serentak-disepakati-digelar-9desember-2020.html 